\title{
THE ACCESS TO THE INTERNET AS A FUNDAMENTAL RIGHT TO STRIKE EFFECTIVENESS IN DIGITAL SOCIETY
}

\section{O ACESSO À INTERNET COMO UM DIREITO FUNDAMENTAL À EFETIVIDADE DA GREVE NA SOCIEDADE DIGITAL}

OTON DE ALBUQUERQUE VASCONCELOS FILHO

Adjunct Professor of Labor Law of the Law Undergraduate Courses at the University of Pernambuco - UPE and Centro Universitário Tabosa de Almeida - ASCES-UNITA. Doctor in Dogmatic Theory of Law by UFPE (Recife, PE, Brazil). Master in Law by UFPE. President of the Luso-Brazilian Academy of Legal Sciences - ALBCJ and Member of the Pernambuco Academy of Labor Law - APDT. Leader of the Law Research Group and the Post-Modernity Conflicts registered with CNPq. Email: otonvasconcelosfilho@gmail.com.

MOACIR BARBOSA MORAIS

Graduating from the 10th period of the Law Course of the University Center Tabosa de Almeida - ASCES- UNITA. Participant in the Law Research Group and the PostModernity Conflicts registered with CNPq. Email:moacirmorais2009@hotmail.com.

\section{VIVIAN ALVES DE MEDEIROS}

Participant in the Law Research Group in the University Center Tabosa de Almeida ASCES- UNITA. Email: medeirosvivian@hotmail.com.

\section{ABSTRACT}

Objectives: The present paper investigates the importance and the fundamentals of the right to access to internet as a constructor resource and a signifier of the exercise of the right to strike in the digital society. The study was developed by way of 
literature review based on titles contained in Scielo, Capes, Virtual Libraries and normative texts that are comprehensive to the international pacts and national legislations of several countries.

Methodology: By way of hypothetico-deductive method and the use of interdisciplinarity, it was identified that the context of technological evolution, of the emergence of new modalities and subjects of labor relations, provided crises in the union model that are still limited to the context of subordinate work that predominated in industrial society.

Results: In the informational society access to internet has gained relevance as its character of universality and indispensability for social development have made it a fundamental human right with a decisive character in the strength and effectiveness of collective struggles. Therefore, in order to exercise the right to strike to be in harmony with the digital society, it is necessary to adapt the strike movement to the context of multiple working relationships and to provide access to Internet as a fundamental right.

Contributions: This paper has as contribution to evidence the importance of internet utilization as a fundamental right.

Keywords: Internet access; fundamental right; strike; work relationships; digital society.

\section{RESUMO}

Objetivo: $O$ presente artigo científico investiga a importância e a fundamentalidade do direito ao acesso à internet como um recurso construtor e ressignificador do exercício do direito de greve na sociedade digital. O estudo desenvolveu-se através da revisão de literatura, a partir de títulos contidos nas bases de dados Scielo, Capes, Bibliotecas Virtuais e textos abrangentes à normas e decisões judiciais prolatadas no Brasil, Itália, França e pela Organização das Nações Unidas.

Metodologia: Através do método hipotético-dedutivo e do uso da interdisciplinaridade foi identificado que o contexto de evolução tecnológica, de surgimento de novas modalidades e sujeitos das relações trabalho proporcionaram crises no modelo sindical que ainda estão limitados ao contexto de trabalho subordinado que predominou na sociedade industrial.

Resultados: Na sociedade informacional, o acesso à internet ganhou relevância, pois seu caráter de universalidade e imprescindibilidade para o desenvolvimento social requer o seu reconhecimento como um direito humano fundamental com 
caráter decisivo na força e efetividade das lutas coletivas. Sendo assim, para que o exercício do direito de greve entre em sintonia com a sociedade digital, é necessária a adequação do movimento paredista ao contexto de múltiplas relações de trabalho e o reconhecimento do acesso à internet como um direito fundamental.

Contribuições: $O$ artigo teve por contribuição colocar em evidência a importância da utilização da Internet como direito fundamental

Palavras-chave: Acesso à internet; Direito fundamental; greve; relações de trabalho; sociedade digital.

\section{INTRODUCTION}

The mutability character of society always gave birth to new rights, many of these were of sufficient relevance to be considered by the legal systems as fundamental and within the scope of labor relations such context was no different. Various achievements of the working class arising from collective struggles during the period of the welfare state have given the recognition to a range of rights that today ensure minimal protective tutelages for the working class.

In the context of contemporary society new forms of labor exploitation have emerged which need to be monitored and combated not only by state entities, but also by the workers themselves with the intermediation of collective entities. At the present time, these organizations have been losing their strength by focusing on outdated organizational policies, not adapting to the new contexts of labor relations and the advancement of the means of interaction between people through the new media.

With this reality there is a need to use the new media technologies intermediated by access to the Internet as facilitators of the effective union of the working class, a new union that will resignify the interests promoted in the Manifesto of the Communist Party (MARX, ENGELS, 1999).

Through the recognition of access to the Internet as a fundamental right and as a factor in the realization of its real reach in society, since many of the great social 
movements are intermediated by such an instrument of social communication, this resource becomes a facilitator of the collective struggles of the working class, which increasingly requires a new standardization, since the prevailing model of the industrial society context no longer fits the scenario of the 21 st century.

The analysis of this new dynamic organization of social movements through the recognition of access to the internet as a fundamental right is justified by the importance of such a postulate for society, which in each period of history had to organize itself in different ways to maintain its quality if subjects protect those who have already been captured. Access to the global computer network is in fact a tool that needs to be recognized as relevant to society as evenly as possible.

Using the hypothetic-deductive method, taking into account the interdisciplinarity of the social sciences, it was possible to consider the concept of fundamental rights and the contexts of superexploitation of labor in the scope of employment relations and the new modalities of work of the 21 st century as basic factors to make a connection with the consolidation of the right to access to the internet as fundamental so as to be an intervening factor in a new context of idealization of collective struggles.

This work was developed by way of the literature review, based on titles contained predominantly in the databases Scielo, Capes and Virtual Libraries and aims to demonstrate the importance of recognition of access to the Internet as a fundamental right for a society formed by new contexts of work relations, by constant flow of information. This can become a decisive factor in the construction of a new dynamics of utilization that aims to give effectiveness to collective struggles. 


\section{CONTEMPORARY THEORIES OF FUNDAMENTAL RIGHTS IN ROBERT ALEXY; BODO PIEROTH AND BERNHARD SCHLINK AND INGO WOLFGANG SARLET}

Among the theories that marked the development of perspectives on fundamental rights, the research established its doctrinal framework from the theoretical propositions of Robert Alexy, Bodo Pieroth with Bernhard Schlink and with Ingo Wolfgang Sarlet.

Alexy dealt with fundamental rights in an analytical way, considering that the character of fundamentability proposes the priority over all levels of the legal system. (ALEXY, 1999, p. 55-66) The author elaborated his theory of fundamental rights based on the typology of "legal norms", which species are: rules and principles.

In the concept of a norm called "semantic concept", Alexy has taken into account its importance for the understanding of fundamental rights and to overcome doubts about the differentiation between principles and rules, established that the norms have determinations within what is factually and legally possible, whereas the principles are, therefore, commandments of optimization characterized by satisfaction to varying degrees and by the fact that the due measure of its effectiveness depends not only on the factual possibilities but also on the legal possibilities. (ALEXY, 2006, p.90-91)

From these introductory explanations Alexy elucidated that the norms of fundamental right can be divided into two groups: those directly constituted by the constitution and the normative texts attributed to it. The first group corresponds to the norms textually put in the constitution and the second one, however, is the result of a more comprehensive interpretation of the constitutional provisions. (ALEXY, 2006, p. 66-74)

Bodo Pieroth and Bernhard Schlink analysed fundamental rights by taking German law into account. For these doctrines, these prerogatives historically have two aspects: one related to natural rights, which are inherent to the human race, and another to those that appear after the advent of the State that would be the entity to 
grant these rights in a real phase of positivation only being fundamental the rights that the state legislature consider through normative. (PIEROTH; SCHLINK, 2012, p. 37)

Pieroth and Schlink's definition of fundamental rights takes two forms which act together to encompass natural, universal rights and the rights identified by the legislator. From this understanding, these authors conclude that fundamental rights are in fact inherent to the human race and can be recognized by the normative way by the State.

Indeed, much of the question revolves around the fact that legal reserves allow the legislature to interfere with their own fundamental rights or to authorize management to interfere with them. Through these limits imposed by the legislator the borders are determined to the exercise of fundamental rights. (PIEROTH; SCHLINK, 2012, p. 85)

From the relations between individuals and the State, Fundamental Rights have gained a larger outline and this is the reason why Pieroth and Schlink also remembered in their work the three different statuses of fundamental rights: status negativus; status positivus and status activus. The first refers to the rights that guarantee the citizen autonomy and freedom before the State body protecting it from interferences in freedom and property; the second demands the intervention and participation of the State as is the case of the right to protection, right to assistance of the community; and the third is where the individual exercises his or her freedom in and for the State, helping to build it by participating in its formation. (PIEROTH; SCHLINK, 2012, p. 62-65)

Sarlet understands that the fundamental rights are those internationally recognized with universal character and positive in the constitutional legal order. The author initially defines them as: legal, minimum and unpredictable positions of the human person, affirmed and granted in the constitutionalism intrinsic to each State, which purpose is the protection of goods that are prominent or threatened. (SARLET, 2012. p. 36; 66) 
In this line of understanding, Sarlet also noted that fundamental rights have reached their institutional fullness within the constitutional state, since they integrate an axiological system and act as a material foundation of all legal order. (SARLET, 2012. p. 70-72)

Contextualizing the question, the author clarifies that there are three periods that deserve prominence in the process of recognition of fundamental rights, they are: the prehistoric moment, which lasted until the end of the sixteenth century; the intermediary, concerning the doctrinal moment of jusnaturalism; and the consequent affirmation of the natural rights of man and the period of the constitutionalization, beginning in 1776, coming from the declarations of rights of the new American states. (SARLET, 2012. p. 44)

Sarlet concluded that the fundamental rights listed in the Constitution of the Federative Republic of Brazil of 1988 sought to combat all forms of state authoritarianism. In a second moment, these rights appeared as fences to omissions of the State in the realization of the minimum rights, something essential for the consolidation of the state organ. (SARLET, 2012. p. 72)

However, even in this line of nationalization of fundamental rights Sarlet understood that these will always be human rights, since the holder of both categories, regardless of the mode of representation, is always the person. In order to complement this concept, the author has made a distinction by clarifying that fundamental rights (broad meaning) relate to those rights of man positively recognized by Constitutional Law, while human rights refer to legal positions of international law, or be those destined for all peoples and at all times. (SARLET, 2012. p. 35-36)

Although the legal institutional recognition given to fundamental rights must be perceived through the notions of freedom and dignity of the human person, one can not pretend to "summarize" them to the category of human rights because they have a more comprehensive, consonant character to a universal legal morality. (SARLET, 2012, p. 36-44) 
Faced with the exposition of a whole script of theories about the fundamental rights that these four authors dealt with, it is possible to understand their agreement on a basic aspect of these rights and their possibility of expansion, since the recognition of new fundamental rights by the normative way is something historically realized in a world in which the mutability of human relations is present. This premise of recognition of new rights by the normative way is worthy of attention in the world of Labor Law.

\section{THE EMPLOYMENT RELATIONSHIP AS A REFERENCE CENTER FOR LABOR LAW IN INDUSTRIAL SOCIETY}

Over the last three centuries, employment relations have gained prominence in the context of human labor with the onset of the industrial age and the emergence of the capitalist production system. The Industrial Revolution that began in England and that over the decades spread to Europe and the United States was a triggering factor for such a change in the way of analyzing labor relations.

The population at that time began to experience unprecedented historical growth, as the standard of living of ordinary people underwent sustained growth that made it easy to rise financially. The work began to be seen as indispensable for the elevation of the human being, becoming an element of dignification. Due to the importance that the work has in the society, Everaldo Gaspar Lopes de Andrade highlights the meaning that the work began to have within the political economy through its own productivity, which was not confused with the products of labor, but with the human force itself, whose intensity was not exhausted after it produced the means of subsistence and survival. (ANDRADE, 2005, p. 36)

The capitalist system of production in all its phases was supported by wage labor and its characteristics were fundamental for this mode of production to obtain exorbitant levels of profit, being a classic example the Fordist system of production that was rationalized through the exercise of specialized functions and automated by 
workers. In this context an attempt to contain the exploitation of capital in the face of workers that Labor Law has emerged as a protective and regulatory instrument that aimed to humanize the relationships established within the major industries. (ANDRADE, 2005, p.45)

In view of various conceptions of work that shaped the understandings of scholars in the nineteenth and twentieth centuries on this subject, attention is drawn to Karl Marx's relationship between wage labor and productive capital, more specifically in the production of capital through the expropriation of value of the work of the proletariat by the owners of the means of production, a situation which he called "value-added".

For Marx, in the capitalist system the concept of productive worker gains importance because the capitalist production is not only the production of commodities, it is essentially the production of surplus value. The worker produces not for himself, but for capital. It is not enough, therefore, that produces in general, it has to produce surplus value; only the worker who produces surplus-value for the capitalist or serves the self-valorization of capital. (MARX, 1984, p. 105)

In the nineteenth and twentieth centuries the employment relationship became the criteria that defines the social significance of individuals. It was through the exercise of employment that the human being came to acquire the goods and services that one needs, because in return one would receive a salary with which would buy what is necessary to survive or at least what could be acquired to live.

Being in an employment relationship in the working world of the late nineteenth and early twentieth century was essential, it was a watershed to be or not someone excluded from society. In other words, formal employment became the basis for the functioning of the economy and became something to be defended as a social right. This problem has become too important for the world, so that with the creation of the International Labor Organization (ILO) a number of antiunemployment policies have emerged.

The need for containment of unemployment is confirmed by Felício Oshiro and Rosa Maria Marques, who demonstrate this by clarifying that the ILO as the heir 
of the social reformers had the initial task of building social norms in the field of labor for all its member countries, which had different degrees of industrialization, was confirmed in 1919 when the first International Labor Conference was held in Washington, where discussions focused on ways of preventing unemployment and remedying its consequences. (OSHIRO; MARQUES, 2016, p. 297)

Another striking moment for employment relations in the twentieth century was the crisis of 1929, the fall of the American stock market moved directly with the perspective of analyzing these relations. From this moment on, the search for an understanding of the causes of unemployment and the means of combating them began, so that the statistics are also intended to serve to anticipate and reflect changes in the labor market. (SAUTHIER, 2009, p. 10)

In the second half of the twentieth century, "mass" labor in the market, or employment, has declined in virtually every industrialized nation in the world. "Intelligent machines" began the process of replacing humans in countless tasks, pushing millions of workers into the ranks of unemployment and unemployment. Such a modification of the context of the adequacy of employment relations to society also had a direct influence on the introduction of neoliberal policies in the world as early as the 1980s, stemming directly from the insecurity experienced by the crisis of the Welfare State.

In this new reality, the growth of neoliberalism prevailed in the capitalist model and the new market economy is affirmed. In this system, transnational corporations, corporations and conglomerates have acquired pre-eminence over national economies. (IANNI, 1995, p. 46)

Supporting the process, a new international division of labor and the flexibilization of production processes have emerged on a global scale. José Dari Krein, who studies the reality of employment relations in Brazil, analyzes that such a change occurred only in the 1990s and was due to the fact that these changes are the result of three combined processes that refer to the reorganization of the economic and political order based on the hegemony of neoliberalism, the productive restructuring and the flexibilization of labor relations. (KREIN, 2013, p.15) 
Despite this scenario, it can not be denied that in the twentieth century formal employment constituted an instrument for the insertion of state policies that aimed at promoting social rights, materializing as fundamental to society. In the context of constitutional evolution in the world, the principle of the dignity of the human person with its necessary social dimension along with the principle of subordination of property to its socio-environmental function, and the principle of valorization of work and, in particular, employed the affirmation of labor law in the legal systems of the last centuries. (DELGADO, 2007, p.14)

From this constitutional reading of the principle of valorization of labor, it is possible to understand that the notion of valorization of regulated labor, which in the capitalist system was basically confused with formal employment. In this context, the constitutional position of Brazil is justified, for example, in its Federal Constitution of 1988, in Title VII "Economic and Social Order", in the chapter of the "General Principles of Economic Activity" to establish as a principle the search for full employment, in Article 170, item VIII.

The fundamental rights included the right to employment and to work regulated and protected by law, either through the realization of the principle of the dignity of the human person or through the promotion of values of social aspects of work.. Based on the normative plan for the regulation of the labor contract, a standard of affirmation of the value of work and dignity of the human being was ensured by the labor contract for most workers in capitalist society (DELGADO, 2007, p. 27)

\section{CAPITALISM AND DIGITAL SOCIETY: THE METAMORPHOSIS IN THE LABOR WORLD AND THE EXPLORATION OF HUMAN LABOR IN THE CONTEXT OF THE MULTIPLICITY OF THEIR RELATIONS}

In a society based on the capitalist system of production and marked by technological development, the mutability character of labor relations has gained 
increasing prominence since the economic system of capitalist production, which is premised on private for-profit means of production and distribution, has undergone changes with the new models of labor relations derived from the evolution of the means of production.

It is necessary to reflect to understand that in a general way the world of work today is composed as Marx thought, for productive work and also for the unproductive. (MARX, 1984, p. 105) For instance, it is possible to focus on the contemporary capitalist system as a facilitator of changes in the labor market, explaining that the changes provided by contemporary capitalism in society are expressed by the globalization of finance, by the increasing precariousness of labor relations, by the high rates of unemployment, the geographical displacement of laborabsorbing and productive bodies and the elimination of jobs in industry and services. (WOLECK, 2002, p.10)

In this line of thinking, Ricardo Luis Coutro Antunes analyzes the question of work under a general prism of evolution of differentiated production and labor sectors, contextualizing a new plan for the possibility of labor exploitation. (ANTUNES, 2006, p. 49)

This panorama of transformations in the economic system and in the labor market as a whole is perceived by Manuel Castells as an essential factor of analysis. Technological evolution and the change of a society in which communication on a large scale has undergone profound technological and organizational transformation based on horizontal networks of multidirectional, interactive communication on the Internet; and even more in wireless communication networks, nowadays the main communication platform everywhere. (CASTELLS, 2009)

In this sense Marina Patrício de Arruda and Lilia Aparecida Kanan acknowledge that work in the digital age aggregates a global understanding of a set of tasks, besides requiring openness to new learning as the new technologies that are the result of human creation are not only auxiliary tools for traditional activities. (ARRUDA; KANAN, 2013 p. 590) 
The authors understand that what is known as the "digital lifestyle" is already underway, since the computer, the Internet and the networks are intelligence technologies and begin to broaden the educational base of society which, in turn, will also influence work processes. (ARRUDA; KANAN, 2013 p. 590)

The introduction of new models in the treatment of the worker's qualification is visible in technological development in which there is a contradictory movement of disqualification of the work of some by the "superqualification" of the work of others; it means a polarization of the required qualifications that results of a particular form of division of labor increasingly derived from the "intelligence" of production.

From the technological development in line with the evolution of the capitalist production system, it is possible to visualize a new context of labor relations that has increasingly spread throughout the world. The emergence of a new context of labor exploitation is evident not only for employment relations but for a whole complexity of modalities of work that emerges in the 21 st century.

This reality shows a new way of perception of exploration. New forms of abusive use of labor arise from adaptations of the labor market every day. Antunes and Praun, on this issue analyze that:

[...] on the one hand, workers belonging to the nucleus that works with more advanced machinery equipped with greater technology are increasingly exposed to the flexibility and intensification of their activities, expressed not only by the cadence imposed by the robotization of the production process, but also, above all, by the institution of practices guided by multifunctionality, polyvalence, interdependent work teams and submission to a series of management mechanisms based on psychological pressure aimed at increasing productivity. On the other hand, another portion of the working class, numerically superior, begins to experience more and more different types of ties and working conditions that are feasible from work environments that articulate less technological development to more extensive journeys, greater insecurity and vulnerability.

${ }^{1}$ (ANTUNES; PRAUN, 2015, p. 411). (Our translation)

\footnotetext{
${ }^{1}$ Original text in Portuguese:[...] por um lado, os trabalhadores pertencentes ao núcleo que atua com maquinário mais avançado, dotado de maior tecnologia, encontram-se cada vez mais expostos à flexibilização e à intensificação do ritmo de suas atividades, expressas não somente pela cadência imposta pela robotização do processo produtivo, mas, sobretudo, pela instituição de práticas pautadas pela multifuncionalidade, polivalência, times de trabalho interdependentes, além da submissão a uma série de mecanismos de gestão pautados na pressão psicológica voltada para o aumento da produtividade. Por outro, outra parcela da classe trabalhadora, numericamente superior,
} 
This question does not refer only to the scope of compensation subordinate work; the other types of work have peculiar characteristics which disguise a context of exploitation in a disguised way. (VASAPOLLO, 2005, p.10) People excluded from the formal labor market migrate to entrepreneurship, informal work, free lance work, domicile work or even to a group of unemployed, which is becoming more common everyday given the context of unemployment.

It is possible to understand that what is presented as freedom of labor and respect for the individuality of the worker is only a form adequate to the capitalist mode of production, especially when accumulation is dependent on flexible relations. By means of this premise it is possible to visualize the provisional character of the capitalist formulations, expressed in the metamorphosis of postmodern society. (TAVARES, 2015, p. 51)

The twenty-first century experiences a set of difficulties due to the different types of work, which always end up bringing in disguise different forms of precariousness. In fact, new working conditions are always inclined to promote the loss of more social rights and guarantees; many of these relationships, whether free lance, informal, domicile or even subordinate work become precarious without any guarantee of continuity. In this scenario, the worker is at a uncertain border between occupation and non-occupation and also in the uncertainty of legal recognition of basic social guarantees.

Not only organizational changes but also the changes in the nature of machinery and the means of work that make it less and less necessary direct human intervention and intensify the requalification requirements of workers who act in direct activities or auxiliary to immediate production. A notorious example of such a reality is the beginning of the use of artificial intelligence in private education, as is the case with the innovative teaching system launched in November 2017 by the Saint Paul business school that offers a corporate education platform for subscription that

passa a experienciar, cada vez mais, diferentes modalidades de vínculos e condições de trabalho que se viabilizam a partir de ambientes de trabalho que articulam menor desenvolvimento tecnológico a jornadas mais extensas, maior insegurança e vulnerabilidade. 
integrates intelligence IBM Watson with e-learning, video and library resources. (YOSHIDA, 2017)

Nowadays, the worker, subordinate or not, is in a context of overexploitation and, in order to overcome the competition, one needs to invest in oneself and improve the technical qualities in order to guarantee the quality of goods and services produced. In this scenario of competition that one observes the fact that technological evolution and the technical professional development of society do not walk together and, facing this issue of needing to maintain some working relationship, seek professional qualification and incline to new working modalities, it is noticeable the severe consequence of the expansion of structural unemployment reaching the world on a global scale.

A new international division of labor exploitation has been established in the field of subordinate work as well and, at the same time, a new context of occupational accidents and diseases. Within large corporations, these changes are evident as the management of work processes is enhanced by the presence of advanced technology. (ANTUNES, 2009, p. 181)

The context of overexploitation and multiplicities of labor relations presented will result in a set of aggravating factors for the worker, who increasingly needs new protection and new ways of organizing their agents in intermediations that deal with collective rights. These factors justify the intervention of intermediaries of protective guardianships considering that in general there is not effectively a real protection by the normative route for all new modalities of work.

\section{THE INEQUICITY OF TRADE UNION WORKERS AND THE PROTECTION OF STRIKE LAW}

Given the context of overexploitation and multiplicity of labor relations in which employment relations no longer predominate in the labor market, it is evident the need to modulate the instruments of collective protection of workers because the 
organization of the modes of claim is not appropriate to the post-industrial society. The importance of trade unionism is highlighted as the claims of collective rights pass through the intermediation of trade unions. Oton de Albuquerque Vasconcelos Filho and Bruno Manuel Viana de Araújo deal with this issue, highlighting an evident crisis of the union model:

[...] the union model is not connected with new technologies, which can be used as a tool to bring workers together, and thus broaden the speech foreseen in the Communist Party Manifesto of 1948. Advances in this direction are insufficient because the legislation that regulates the union system is aimed at workers, predominantly. ${ }^{2}$ (VASCONCELOS FILHO, ARAÚJO, 2017, p. 45) (Our translation)

The first reason for declination is due to the crisis of disaffiliation, which is connected to structural unemployment. Due to the insecurity in the maintenance of their functions, which did not happen in the splendor of the State of Social Welfare in which there was full employment, a large part of the population withdrew from the trade union discourse trying to preserve their jobs. (VASCONCELOS FILHO, 2008. p. 49)

The second factor of crisis is related to the growth of the service sector; in the industrial period of full employment the majority of the workers transited in the commerce and industry facilitating the agglutination of workers to assert rights, which did not occur with the increasing demand when there was a separation of the working class of this sector of severe importance in the post-industrial society, becoming more difficult for the union commands to bring together workers of different professional categories in a universe of fragmentation in which the multiplicity of business types predominate. (ANDRADE, 2005, p. 93)

In such crisis of ineffectiveness of trade union it is possible to emphasize the non inclusion of the new social movements in the syndical model, in order to be perceivable the non-accompaniment of this to the new reality of social movements. 2 The original text in Portuguese: [...] o modelo sindical não se encontra conectado com as novas
tecnologias, que podem ser utilizadas, inclusive, como ferramenta para juntar os trabalhadores, como
gênero, e assim ampliar o discurso previsto no Manifesto do Partido Comunista, de 1948. Os avanços
nesse sentido são insuficientes porque a legislação que regulamenta o sistema sindical encontra-se
direcionada para obreiros, predominantemente 
The idea of seeking and protecting the excluded classes has not prevailed in the syndical model in the post-industrial society, as new categories of social movements arise every day and in many cases the claims are indirectly linked to the search for a dignified life in a decent work. In Brazil, the Movimento dos Sem Terra (MST), the professional truckers and the street vendors are all examples of such social movements. However, for most of those who discuss Labor Law, the formation of a trade union category is limited only to the composition of workers. (VASCONCELOS FILHO, 2008, p. 51)

The question of social solidarity is put in check at such moment in order to reach higher levels of specific strike contexts in which solidarity and action of various categories of workers will have to be linked, since often the victory or defeat of a strike in one or more countries depend on the support, solidarity and action of workers in other productive units of a production sector. (ANTUNES, 2009, p. 116)

It is noticeable that the trade union movement of workers is present in several modalities, this is the reason why for many people it has been called "new", like the picketers in Argentina, that have diverse and heterogeneous social composition. (GOHN, 2011, p. 338)

Finally, it is still worth mentioning that the mismatch between the industrial worker and the new communication alternatives of the present time is more related to the present work. It is vital for the existence and development of trade unions to adopt a new type of relationship with virtual communication, since it has now provided the great majority of social movements.

Today, the main social movements work through social networks, local, regional, national and international or transnational and make new media and information, such as the internet. The creation and development of new knowledge today are also products of this communicability. (GOHN, 2011, p. 336)

It is noticeable that the right to strike as an instrument of collective struggles has been undermined, mainly because the union model does not follow the metamorphosis of the world of work that have withdrawn a huge range of workers from the formal labor market and are not updated to the new society that values 
technological development and the use of digital media. In this sense, Vasconcelos Filho and Araújo, when dealing with the connection with the right to strike and collective struggles in Latin America, analyze that:

[...] the international documents and legislation of the countries that make up Latin America still have a vision of unionism and collective struggles linked to the struggles between employees and employers through their trade union organizations and, with a purely claim basis. ( ${ }^{3}$ (VASCONCELOS FILHO; ARAÚJO, 2017, p. 49) (Our translation)

The need to adapt the strike as a social movement in the context of the postindustrial society through the inclusion organized by unionism of the categories excluded from its protection is visible, as well as the adoption of measures adaptive to the new technological context that the society lives, through a new perspective of social solidarity. In this scenario, it is fundamental to include the new means of facilitating social communication through access to the Internet as a means of developing collective struggles.

\section{INTERNET ACCESS AS FUNDAMENTAL LAW FOR THE EFFECTIVENESS OF COLLECTIVE STRUGGLES}

In the last decades the access to the worldwide computer network has been consolidating like an instrument very important for the social movements and the collective fights. Manuel Castells deals with its relevance to society, emphasizing that:

Networks are open structures, able to expand without limits, integrating new nodes as long as they are able to communicate within the network [...] networks are appropriate instruments for a capitalist economy based on innovation, globalization, and decentralized concentration; for work, workers, and firms based on flexibility and adaptability. (CASTELLS, 2010, p. 501)

${ }^{3}$ Original text in Portuguese: [...] os documentos internacionais e a legislação dos países que compõem a América Latina ainda tem uma visão de sindicalismo e das lutas coletivas vinculadas às lutas entre empregados e empregadores, através de suas organizações sindicais e, com eixo puramente reivindicativo. 
Such relevance is considered in check when a space is opened for the treatment of Internet access as a fundamental right since there is a range of scholars on the subject that, like Ingo Wolfgang Sarlet, list as fundamental only those rights that in this way are described and postulates in constitutional texts.

The first step is to legally recognize this right as a human right following the guidelines of International Law, the United Nations (UN) guidelines, which on May 16, 2011 recognized access to the internet as a human right. According to the UN, preventing access to information through the use of technology violates Article 19, paragraph 2, of the International Covenant on Civil and Political Rights of 1966. (OLIVEIRA; SILVA, 2014, p. 233)

The media focusing on the issue of freedom of expression, the prohibition against censorship and the right to information itself is an introductory parameter for the consolidation of access to the internet as a fundamental human right since, as a means of facilitating communication between people, such a right implicitly lies in such precepts being obtained and made available constantly, infinite information by the worldwide computer network. By means of this interpretation, it is possible to assume that the holder of this right by being prevented from exercising it or by the simple fact of not having the factual conditions for the exercise of the right, has the human dignity disrespected or disregarded. (FERREIRA PES, 2015, p.12)

Therefore, it is possible to maintain that access to the internet has support to be included in the list of fundamental rights. Considering the importance of such a right for society and that the constitutional texts of most of the countries of the world follow trends adaptive to international law. This tendency is verified in the Brazilian experience when observing the Proposed Amendment to the Constitution (PEC) number 479/2010, which is being processed by the Chamber of Deputies since 2010. It intends to add section LXXIX to Article 5 of the 1988 Federal Constitution to include high-speed Internet access among the fundamental rights of the citizen. (BRASIL, Proposta de Emenda à Constituição № 479, 2010) 
This goal of raising the status of internet access as a fundamental right is also followed in Europe. In May 2009, the Council of Ministers of Europe published a statement recognizing access to the Internet as a Fundamental Right. Another example relates to the French Constitutional Council that in the same year ruled unconstitutional the bill that intended to block access to the Internet without the need for a judicial decision of people who download copyright material. It is possible to consider such a decision as a benchmark in the recognition of access to the internet as a fundamental human right necessary for access to culture and manifestation of freedom of expression. (GOULART, 2012, p. 160)

The fact that technological development is able to develop new contours of citizenship is justified by the access to information and communication technologies (ICT) to enable a greater debate in the decision-making in the collective contexts, being the Internet also a factor of fomenting political interest by the civil society to strengthen participation in public policy negotiations.

In the light of these conclusions, it remains evident that the internet has proved to be an important tool for creating and maintaining communication channels on a global scale, for the dissemination of opinions, manifestation and political participation. However, these factors may hinder the development of participation in cyberspace and in this speech Antônio Enrique Pérez Luño clarifies that the:

[... T he Internet is creating new forms of inequality between the "info-rich" and "info-poor", by establishing serious discrimination to access and use of information between the North and the South, where the lack of equipment will condemn marginalization to millions of people.. ${ }^{4}$ (LUÑO, 2003, p. 90-91) (Our translation)

Universal access and better technology ownership also have to be recognized that many people are excluded because they find it difficult to navigate and obtain information online due to the low accessibility of many electronic addresses.

${ }^{4}$ Original text in Spanish: [...] Internet está creando nuevas formas de desigualdad entre los "inforicos" e "info-pobres", al establecer discriminaciones graves al acceso y utilización de informaciones entre el Norte y el Sur, donde la falta de equipamientos condenará a la marginación a millones de personas 
The ease in navigating the sites should be a concern of the producers of the page since through this instrument access to the internet will reach everyone regardless of intellectual knowledge. Digital inclusion and the promotion of "digital citizenship" will contribute to a more egalitarian society with the expectation of social inclusion that is in the digital media and, as a point of achievement to the assimilation of information and its re-elaboration in new knowledge, having as a desirable consequence the materialization of social emancipation. (RIBEIRO, 2007, p. 77)

The idea of social movement network is therefore a reference concept that seeks to apprehend the direction of the actions of movement, transcending the empirical, concrete, dated and localized experiences of the collective actors, being directly linked to the antisystemic potential that a social movement in its ability to articulate with other movements.

For the effectiveness of collective struggles, it is fundamental to adopt different strategies that range from simple denunciation, through direct pressure (mobilizations, marches, rallies, riots, organized disobedience, negotiations, etc.) to indirect pressure. At present, the main social movements work through social networks, local, regional, national and international or transnational using the new media and information. (GOHN, 2011, p. 335-336)

Considering the many cross-interests of social movements, new strategies can be shaped in an attempt to exploit these technological resources, through the principle of external articulation in the formation of networks of social movements.

The issue of cyber-activism is highlighted as a crucial factor for social movements, such as the mobilizations that took place: the Green Movement in Iran in 2009, the Arab Spring in Sub-Saharan Africa in 2010, 15M in Spain in 2011, the 8N in Argentina in 2012, the March of the Bums in Canada in 2011 or the Pass Livre movement that gained strength in Brazil in 2013. (SANTOS DA SILVA, 2013, p. 3)

In the reported movements it became clear the interference of social networks in their articulations as in the case of the $8 \mathrm{~N}$ movement (November 8 ) started in Argentina in 2012 that was made by a set of demonstrations organized on social networks such as Twitter and Facebook, mobilizing thousands of people on 
Argentine streets dissatisfied with local public policies. The impact of this movement has attracted activists from various cities around the world, such as in Santiago, São Paulo, Rio de Janeiro, Miami, Milan, Paris, London, Sydney, among others, gaining prominence in the international press. (SANTOS DA SILVA, 2013, p. 3-4)

The use of digital media also encompasses specific job categories through the strike institute. This is the case of Italy that already took the initiative in 2008 to draft Bill No. 1,170 of 2008, which provided for the possibility of virtual strikes by the categories of subordinate workers. Despite this initiative, this project does not meet the primary need to establish a network of global solidarity as it does not consider the multiplicity of labor relations existing in the contemporary world. (SENATO DELLA REPUBBLICA ITALIANA, 2008)

In the Brazilian experience the registration of the strike called "general strike" on April 28, 2017 brought together more than 150 cities in the country, a movement in which trade union centrals called for protests against reforms of laws and proposals to the Brazilian National Congress. This mobilization was the result of the intense use of social networks such as Facebook and Twiter, in which millions of people demonstrated against and in favor of such a general stoppage. (REDAÇÃO RBA, 2008)

In the example of Brazil it is possible to add as a factor of inefficiency the fact that Law No. 7,783 of 1989, which governs the right to strike in Brazil, is still attached to the question of protecting the specific category of subordinate labor. In a crisis context of the industrialist unionist model, it is clear the need to recognize a new role of labor relations subjects to encourage and effect new adaptive tendencies as explained by Vasconcelos Filho and Araújo:

[...] the Labor Law will have to reinvent itself in order to protect this range of workers who are on the sidelines. This reflection is necessary, above all, when analyzing the collective bias of Labor Law. This is because, as already mentioned in the previous item, the unionism experiences several crises and this fact directly impacts on the strike exercise. . ${ }^{5}$ (VASCONCELOS FILHO, ARAÚJO, 2017, p. 46) (Our translation).

\footnotetext{
${ }^{5}$ Original text in Portuguese: [...] o Direito do trabalho terá que se reinventar para poder tutelar essa gama de trabalhadores que se encontram à margem. Essa reflexão se faz necessária, sobretudo,
} 
The need to create a new way of effecting collective struggles is through the search for rights such as digital professional training, computer intimacy, communication, information and expression through tools that communicate technology with information and the computer law of strike. (SAKO, 2014, p. 114)

It is clear from the context of Internet access and its virtual social networks that through these tools it is possible to offer new opportunities to reflect, organize and mobilize people to combat the hegemony of capital over the labor force beyond national territory. Antunes ratifies this idea when he concludes that:

With the expansion of capital on a global scale and the new form assumed by the international division of labor, the responses of the workers' movement assume an increasingly universal meaning. Increasingly, national-level struggles must be articulated with a struggle of international scope. The transnationalization of capital and its productive system forces the working class even more to think of the international forms of its action, confrontation and solidarity. . ${ }^{6}$ (ANTUNES, 2009, p. 223). (Our translation).

The recognition of Internet access as a fundamental right and of states' obligation to implement digital inclusion policies will be possible by way of making activism in virtual media an important resource for the process of promoting collective struggles. It will also facilitate the modulation of a new workers' internationalism in which ideas of solidarity and integration among the new subjects of labor relations are present, in order to provide the democratization of society and respect for the basic precepts guaranteed by its legal systems.

quando analisado o viés coletivo do Direito do Trabalho. Isso porque, como já mencionado em item anterior, o sindicalismo vivencia diversas crises e esse fato impacta diretamente no exercício de greve.

${ }^{6}$ Origina text in Portuguese: Com a expansão do capital em escala global e a nova forma assumida pela divisão internacional do trabalho, as respostas do movimento dos trabalhadores assumem cada vez mais um sentido universalizante. Cada vez mais as lutas de recorte nacional devem estar articuladas com uma luta de amplitude internacional. A transnacionalização do capital e do seu sistema produtivo obriga ainda mais a classe trabalhadora a pensar nas formas internacionais da sua ação, confrontação e solidariedade. 


\section{CONCLUSION}

Faced with a new scenario of labor relations whereby the role of the subjects of has been expanded, it is necessary to emphasize the fact that new forms of overexploitation of labor began to flourish.

The need to create new means of collective protectionfor the working class became essential at the beginning of the twenty-first century and this question, due to the constant character of society's mutability, has as its basic premise the ineffectiveness of syndicalism during the peak of the industrial period prospered in society.

The new complex of working modalities is not adequate to this union model that in the last decades has been suffering with different types of crises that directly interfere in the protection of workers' rights and consequently in the essence of collective struggles.

The right to strike, which was largely used as an instrument of struggles and achievements of the working class, has its effectiveness mitigated by being in disagreement with the complexity of contemporary labor relations, so that the need to use technological resources via Internet access is something that is becoming more and more concrete in the world context in which the great social movements have been used intensively said instrument of communication.

Faced with the technological development that already reaches most of the population of the globe, access to the Internet has become essential for social development and for the exercise of citizenship. This indispensability character gives access to the internet a higher status within the complex of human rights in order to be possible to classify it as fundamental for society.

The recognition of the right to access to theinternet as a fundamental right may be a decisive factor in the model of collective labor protection, given the fact that such recognition would generate a greater intensification of state policies to encourage the exercise of this right, digital activism by the working class as a whole. 
The recognition of access to the internet as a fundamental right is a decisive factor for effecting strikes, adapting these to the new modalities of work and the new technological context, making possible the connection of all the workers in order to provide a new internationalism of the workers.

\section{REFERENCES}

ANTUNES, Ricardo. Adeus ao trabalho? Ensaio sobre as metamorfoses e a centralidade no mundo do trabalho. 11. Ed. São Paulo: Cortez, Editora da Universidade Estadual de Campinas, 2006.

ANTUNES, Ricardo. Os sentidos do trabalho. Ensaio sobre a afirmação e a negação do trabalho. 2.ed., rev. e ampl. São Paulo: Boitempo, 2009.

ANTUNES, Ricardo; PRAUN, Luci. A sociedade dos adoecimentos no trabalho. Revista Serv. Soc., São Paulo, n. 123, p. 407-427, jul./set. 2015. Accessed on: 03 dec., 2017

ALEXY, Robert. Teoria dos Direitos Fundamentais. Tradução de Virgílio Afonso da Silva. São Paulo: Malheiros Editores, 2006.

ALEXY, Robert. Direitos Fundamentais no Estado Constitucional Democrático: Para a relação entre direitos do homem, direitos fundamentais, democracia e jurisdição constitucional. Tradução de Luís Afonso Heck. Revista de Dir. Administrativo, Rio de Janeiro. v. 217, p. 55-66, jul./sep. 1999.

ANDRADE, Everaldo Gaspar Lopes de. Direito do Trabalho e pós-modernidade: fundamentos para uma teoria geral. São Paulo: LTr, 2005.

ARRUDA, Marina Patrício de; KANAN, Lilia Aparecida. A organização do trabalho na era digital. Revista Estudos de Psicologia, Campinas, p. 583-591, oct./dec., 2013.

BRASIL. Constituição da República Federativa do Brasil de 1988. Brasília: Senado $\quad 1988 . \quad$ Federal, 1 ailable <http://www.planalto.gov.br/ccivil_03/constituicao/constitui\%C3\%A7ao.htm>. Accessed on: Dec., 10, 2017.

. Proposta de Emenda à Constituição no 479, de 15 de abril de 2010. Acrescenta o inciso LXXIX ao art. 5० da Constituição Federal, para incluir o acesso à Internet em alta velocidade entre os direitos fundamentais do cidadão. Availabel at: : $<$ http://www.camara.gov.br/proposicoesWeb/prop_mostrarintegra;jsessionid=433820 
E5D0EC1B117ACAB9523A746B5C . proposicoesWeb1 codteor $=756209 \&$ filename $=$ PEC+479/2010>. Accessed on: Dec. 3, 2017.

Lei no 7.783 de 28 de junho de 1989. Dispõe sobre o exercício do direito de greve, define as atividades essenciais, regula o atendimento das necessidades inadiáveis da comunidade, e dá outras providências. Disponível em: <https://www.planalto.gov.br> Accessed on: Dec 3, 2017.

CASTELLS, Manuel. Communication power. New York: Oxford University Press, 2009.

CASTELLS, Manuel. The rise of the network society. Library of Congress, 2nd ed., 2010.

DELGADO, Maurício Godinho. Direitos fundamentais na relação de trabalho. Revista de Direitos e Garantias Fundamentais, n. 2, p. 11-39, 2007.

FERREIRA PES, João Hélio, O direito fundamental implícito de acesso às novas tecnologias da informação e comunicação. Publicado no III Congresso Internacional de Direito e Contemporaneidade: mídias e direitos da sociedade em rede. Santa Maria / RS UFSM - Universidade Federal de Santa Maria, 2015.

GOHN, Maria da Glória. Movimentos sociais na contemporaneidade: A relação movimentos sociais e Educação. Revista Brasileira de Educação. v. 16, n. 47, p. 333-361, May/Aug., 2011.

GOULART, Guilherme Damásio. O impacto das novas tecnologias nos direitos humanos fundamentais: 0 acesso à internet e a liberdade de expressão. REDESG / Revista Direitos Emergentes na Sociedade Global, v. 1, n. 1, Jan./Jun. 2012.

IANNI, Octavio. A sociedade global. 3.ed. Rio de Janeiro: Civilização Brasileira, 1995.

KREIN, José Dari. As transformações no mundo do trabalho e as tendências das relações de trabalho na primeira década do século XXI no Brasil. Revista NECAT, Ano 2, no 3, Jan./Jun. 2013.

LUÑO, Antonio Enrique Péres. Derechos humanos, estado de derecho y constitucion. 8. Ed. Madri: Tecnos, 2003.

MARX, Karl. O capital: Crítica da Economia Política. O processo de produção do capital. São Paulo: Abril Cultural, v. 1, tomo 2, 1984.

; ENGELS, Friedrich. Manifesto do Partido Comunista. 9. ed. Petrópolis, RJ: Vozes, 1999. 
OLIVEIRA, Gislaine Ferreira; SILVA, Rosane Leal da. A universalização do acesso à internet como novo direito fundamental: das políticas de inclusão à educação digital. Congresso Nacional do CONPEDI/UFPB, págs. 228-253, 2014.

ONU - Organização das Nações Unidas. Pacto Internacional dos Direitos Econômicos, Sociais e Culturais. 1966. Available at: <http://www.planalto.gov.br/ccivil_03/decreto/1990-1994/d0591.htm>. Accessed on: Dec. 3, 2017.

OSHIRO, Felício; MARQUES, Rosa Maria. O conceito de desemprego e sua medição no século XX. Textos \& Contextos (Porto Alegre), v. 15, n. 2, p. 293 - 307, Aug./Dec. , 2016.

PIEROTH, Bodo; SCHLINK, Bernad. Direitos Fundamentais. Editora Saraiva, São Paulo, 2012;

Redação RBA. Greve geral de 28 de abril já está na história, mas promete desdobramentos. $2008 . \quad$ Available at: < http://www.redebrasilatual.com.br/trabalho/2017/04/greve-geral-de-28-de-abril-jaesta-na-historia-mas-promete-desdobramentos>. Accessed on: Dec. 3, 2017.

RIBEIRO, Maria Thereza Pillon. Inclusão Digital e Cidadania. IX Jornada Multidisciplinar do Pensamento e Linguagem, Bauru/SP, v. 1. P.79-74, 2007.

SAKO, Emilia Simeão Albino. Trabalho e novas tecnologias: direitos on-line ou direitos de 4ª geração. São Paulo: LTr, 2014.

SARLET, Ingo Wolfgang. A eficácia dos direitos fundamentais: uma teoria geral dos direitos fundamentais na perspectiva constitucional. 11. ed. rev. atual. Porto Alegre: Livraria do Advogado Editora, 2012.

SAUTHIER, Ingrid Liebeskind. Histoire de la définition du chômage. Courrier des Statistiques, n. 127, p. 5-12, May/Oct. 2009.

SANTOS DA SILVA, Michele. Ciberativismo nas redes sociais no contexto latinoamericano: apontamentos para o estudo sobre a mobilização argentina 8N. Anais III Fórum Brasileiro de Pós-Graduação em Ciência Política da UFPR, Curitiba, julho/agosto de 2013.

SENATO DELLA REPUBBLICA ITALIANA, Disegno di Legge no 1.170 de 2008, Disposizioni in materia di sciopero virtuale. Available at: $<\mathrm{http}: / / \mathrm{mobile}$.senato.it/japp/bgt/showdoc/frame.jsp?tipodoc=Ddlpres\&leg=16\&id=003 33676\&part=doc_dc \&parse $=$ no\&mobile $=$ si\&index $=$ si\&toc $=$ no $>$. Accessed on: Dec. 3 , 2017 
TAVARES, Maria Augusta. O trabalho informal e sua suposta autonomia: uma modalidade flexível de exploração. Revista Direitos, Trabalho e Política Social. v.1, n. 1, jul/dez. p. 39-58, 2015.

VASAPOLLO, Luciano. O trabalho atípico e a precariedade. São Paulo: Expressão Popular, 2005.

VASCONCELOS FILHO, Oton de Albuquerque. Liberdades Sindicais e atos Antisindicais: a dogmática jurídica e a doutrina da OIT no contexto das lutas emancipatórias contemporâneas. São Paulo: LTr, 2008.

; ARAÚJO, Bruno Manuel Viana de. A greve política como categoria de direito humano na América Latina: reconfigurando as lutas coletivas a partir das novas teorias dos movimentos sociais. Revista Direito e Desenvolvimento, v.8, n.1, p. 39-54, João Pessoa, 2017.

WOLECK, Aimoré. O trabalho, a ocupação e o emprego: uma perspectiva histórica. Revista de divulgação Tecnico-científica do instituto catarinense de PósGraduação. Jan., 1, 2002, p. 33-39

YOSHIDA, Soraia. Saint Paul lança plataforma de ensino com inteligência artificial IBM Watson. 2017. Available at: <http://epocanegocios.globo.com/Carreira/noticia/2017/11/saint-paul-lancaplataforma-de-ensino-com-inteligencia-artificial-ibm-watson.html>. Accessed on: Dec. 3, 2017. 